\title{
БИОМОРФОЛОГИЧЕСКИЕ ОСОБЕННОСТИ LILIUM MARTAGON L.В УСЛОВИЯХ СЕВЕРНОГО И СЕВЕРО-ВОСТОЧНОГО АЛТАЯ
}

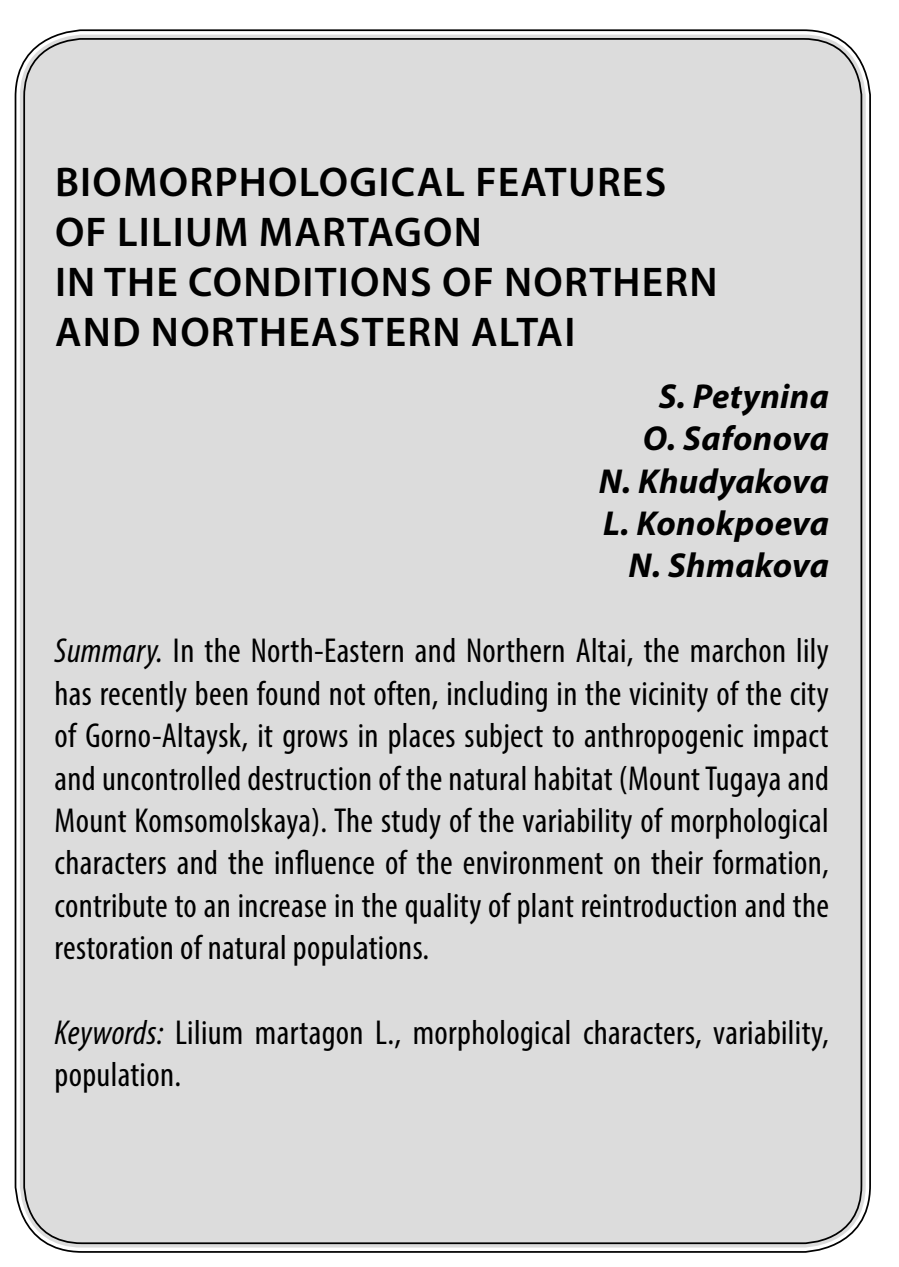

\section{Введение}

$\Pi$ роблема сохранения, рационального использования и обогащения видового и сортового разнообразия цветочно-декоративных растений путем интродукции и селекции является важной и достаточно актуальной в настоящее время. Это ведет к необходимости изучения биологического потенциала растений в различных регионах. Изучение биоморфологических признаков растений позволяет судить не только о внешнем виде растений и состоянии популяции в целом, но и оценить перспективу использования данных особей в селекционных целях. Но последнее время усилился процесс антропогенного воздействия на естественную среду произрастания лилий и ранее распространённый повсеместно в окрестностях г. Горно-Алтайска вид становиться все более редким.
Петунина Светлана Сергеевна

Горно-Алтайский государственный университет petunina-sveta@mail.ru

Сафонова Оксана Владимировна

К.с.-Х.н., доцент, Горно-Алтайский государственный университет

oksvarias@mail.ru

Худякова Надежда Ефремовна

К.б.н., дочент, Горно-Алтайский государственный университет Nch752@bk.ru

Конокпоева Любовь Александровна

Горно-Алтайский государственный университет konokpoeva92@gmail.com

Шмакова Наталья Юрьевна

Горно-Алтайский государственный университет Nataliashmakova1998@gmail.com

Аннотация. В Северо-Восточном и Северном Алтае лилия мартагон последнее время встречается не часто, в том числе и в окрестностях г. Горно-Алтайска, произрастает на местах подверженных антропогенному воздействию и неконтролируемому разрушению естественной среды обитания (гора Тугая и гора Комсомольская). Изучение изменчивости морфологических признаков и влияния среды на их формирование, способствуют повышению качества реинтродукции растений и восстановлению природных популяций.

Ключевые слова: Lilium martagon L., морфологические признаки, изменчивость, популяция.

Морфологические особенности лилий изучались в прошлом веке $[1,4,10]$ и в наше время $[8,9]$ в том числе и уделялось внимание изучение сортов лилий в условиях Горного Алтая [5, 6, 7], но очень мало работ посвящено изучению лилии кудреватой в условиях Алтая.

Основным ограничивающим фактором для выращивания многих видов и гибридных групп в Сибири является температура воздуха и почвы. Наиболее теплолюбивые виды и сорта, созданные на их основе, неперспективны для выращивания в условиях открытого грунта Сибири:

1. из-за короткого вегетационного периода (виды и сорта, цветущие в очень поздние сроки в конце лета - начале осени, например, виды Японии);

2. из-за слабой зимостойкости (виды Средиземноморья или другие с южными ареалами); 
3. из-за периодически повторяющихся поздних является сильных возвратных заморозков (неморозостойкие виды и сорта).

Таким образом использование в селекции вида, который произрастает в данных условиях являться актуальным, так как он наиболее приспособлен к сложившимся на данной территории климатическим условиям.

\section{Метолы и материалы исследования}

За основу для исследования взята методика Злобина Ю.А. [3] адаптированная под исследуемый нами вид.

При популяционных исследованиях основным является изучения морфологических особенностей растений. Любая особь растения характеризуется определенным набором признаков, которые вступают в качестве параметров ее морфологического статуса.

В данном исследовании ключевым стал один из статистических параметров: метрический. За основные критерии взяты признаки: высота растения, длина соцветия, длина и ширина листа, толщина стебля, диаметр цветка, количество бутонов, число одновременно открытых цветков, длина пестика длина тычинки.

На основании имеющихся данных о ряде промеров, можно проследить рост отдельных частей растений и показать в динамике строение ее генеративных и вегетативных органов

Пластичность проявляется в обратимости структур и функций организма при воздействии новых условий жизни. Как правило, пластичность является адаптивной и обеспечивает сохранение жизненной силы особи.

Одни из методов обнаружения пластичности является сопоставление средних арифметических значений для растений разных популяций, разных условий обитания [3].

Исследования проводились в период с 2019 г. по 2020 г.

Эксперимент с культивированием лилий был заложен согласно Методике полевого опыта [2].

Дикорастущие формы выявлены в 2х популяциях:

\section{Южный склон горы Тугая}

Гора высота которой составляет 635 м. над уровнем моря, западный склон которой соприкасается с рекой Майма, биоценоз характеризуется произрастанием растений разных семейств с преобладанием злаковых трав. Травостой довольно густой. Совокупность особей видов на вершине горы Тугая, можно отнести к лесным сообществам с доминированием: в древесном ярусе сосны обыкновенной (Pinus sylvestris), в травяно-кустарниковом ярусе ярко выражены такие виды как земляника лесная (Fragaria vesca), лапчатка гусиная (Potentilla anserina), осока приземестая (Carex supina), лилейник желтый (Hemerocallis lílioasphodelus) и др.

\section{Северный склон горы Комсомольской.}

Высота горы 428м, обмывается с левобережья рекой Маймой.

В основном склон занят березовым лесом, но иногда встречаются посадки хвойных деревьев: пихтой сибирской (Abies sibirica), сосны сибирской (Pinus sibirica).

Травостой так же разнообразен, основное место занимают растения семейства зонтичных: дудник лесной (Angelica sylvestris), володушка золотистая (Bupleurum aureum). Так же встречаються разнообразные представители семейств лютиковых, розоцветных, гвоздичных, лилейных. В травостое встречаются папоротники.

Культивируемые формы рассматривались в 2х населенных пунктах Чойского район Республики Алтай: с. Ынырга и с.Чоя.

\section{Результаты исслеАования \\ и обсу>}

Сравнительный анализ природных популяций показал, что существуют достоверные отличия морфологических признаков растений между исследуемыми пробными площадками.

Lilium martagon на горе Тугая, представлена довольно большой популяцией, на территории в 2000 м² $^{2}$ найдено около 400 особей данного вида в разных онтогенетических стадиях. Удаленность объектов между собой составляла 5-7 м.

Следует отметить, что растения произрастающие на Южном склоне горы Тугая имеют довольно широкий размах показателей по всем признакам. Это может быть связано с неравномерностью распределения объектов исследования по склону. Некоторые изученные объекты произрастали на открытом лугу с достаточным количеством света, а некоторые в тени деревьев, где им не хватает света. Неравномерность влажности и освещения это основные лимитирующие факторы для всех растений в том числе и для лилий. Таким образом, в хорошо освещенных участках горы находились более низкие формы, в то время как в менее освещен- 
Таблица 1. Распределение морфологических признаков Lilium martagon L. (гора Тугая)

\begin{tabular}{|c|c|c|c|c|c|c|c|c|c|c|c|}
\hline & 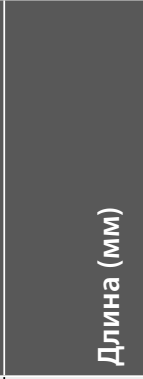 & 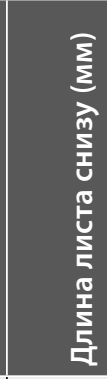 & 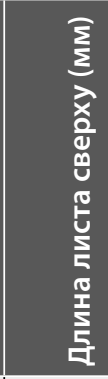 & 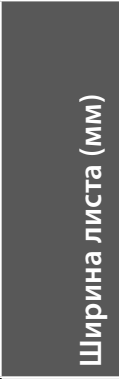 & 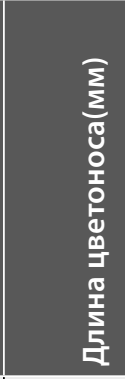 & 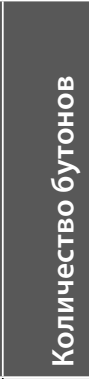 & 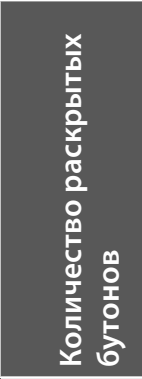 & 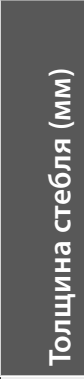 & 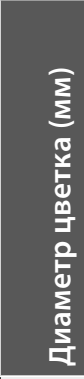 & 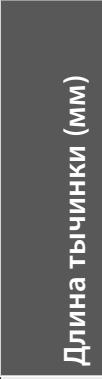 & 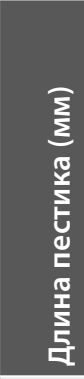 \\
\hline & 930 & 130 & 75 & 15 & 90 & 8 & 5 & 5 & 30 & 25 & 25 \\
\hline & 960 & 90 & 70 & 17 & 80 & 7 & 3 & 3 & 40 & 35 & 35 \\
\hline & 1210 & 95 & 70 & 12 & 70 & 8 & 1 & 4 & 40 & 25 & 33 \\
\hline & 950 & 110 & 60 & 13 & 70 & 6 & 3 & 3 & 40 & 20 & 30 \\
\hline & 430 & 90 & 60 & 15 & 40 & 2 & 2 & 4 & 40 & 30 & 25 \\
\hline & 800 & 90 & 60 & 15 & 80 & 9 & 1 & 3 & 45 & 3 & 25 \\
\hline & 970 & 80 & 40 & 14 & 70 & 6 & 2 & 6 & 35 & 25 & 25 \\
\hline & 910 & 120 & 50 & 16 & 70 & 8 & 2 & 5 & 35 & 35 & 20 \\
\hline & 800 & 90 & 40 & 16 & 50 & 3 & 3 & 4 & 35 & 25 & 20 \\
\hline & 950 & 120 & 70 & 17 & 90 & 9 & 6 & 5 & 40 & 30 & 25 \\
\hline & 930 & 85 & 65 & 16 & 70 & 5 & 5 & 4 & 35 & 25 & 20 \\
\hline & 650 & 80 & 50 & 16 & 65 & 3 & 2 & 6 & 30 & 20 & 20 \\
\hline & 750 & 100 & 50 & 15 & 60 & 4 & 4 & 4 & 25 & 20 & 20 \\
\hline & 1150 & 90 & 60 & 14 & 100 & 9 & 2 & 5 & 40 & 25 & 25 \\
\hline & 620 & 60 & 50 & 12 & 30 & 4 & 2 & 4 & 30 & 20 & - \\
\hline & 690 & 90 & 50 & 12 & 60 & 3 & 1 & 5 & 50 & 25 & 20 \\
\hline & 680 & 110 & 50 & 115 & 60 & 8 & 2 & 4 & 35 & 25 & 20 \\
\hline & 960 & 110 & 50 & 31 & 60 & 8 & 2 & 3 & 35 & 25 & 20 \\
\hline & 860 & 75 & 65 & 15 & 30 & 7 & 3 & 4 & 45 & 35 & 30 \\
\hline & 1130 & 85 & 55 & 15 & 40 & 8 & 4 & 5 & 40 & 30 & 25 \\
\hline & 1235 & 90 & 65 & 15 & 100 & 9 & 3 & 3 & 35 & 35 & 30 \\
\hline & 760 & 100 & 65 & 16 & 80 & 3 & 3 & 3 & 35 & 35 & 30 \\
\hline & 690 & 95 & 55 & 17 & 50 & 6 & 2 & 3 & 25 & 25 & 20 \\
\hline & 575 & 70 & 40 & 15 & 40 & 4 & 3 & 3 & 35 & 35 & 30 \\
\hline & 1505 & 70 & 40 & 11 & 100 & 10 & 6 & 11 & 25 & 25 & 20 \\
\hline & 730 & 80 & 50 & 11 & 45 & 4 & - & 3 & - & - & - \\
\hline & 1200 & 130 & 90 & 14 & 60 & 8 & 4 & 4 & 60 & 25 & 20 \\
\hline & 1250 & 120 & 90 & 15 & 55 & 7 & 5 & 5 & 50 & 45 & 45 \\
\hline & 950 & 110 & 90 & 15 & 65 & 5 & 4 & 3 & 40 & 40 & 35 \\
\hline & 790 & 60 & 40 & 15 & 50 & 3 & 3 & 3 & 30 & 30 & 25 \\
\hline & 865 & 73 & 43 & 14 & 40 & 7 & 2 & 4 & 45 & 45 & 35 \\
\hline & 755 & 75 & 40 & 15 & 35 & 4 & 4 & 4 & 50 & 45 & 45 \\
\hline & 800 & 80 & 60 & 12 & 40 & 10 & 5 & 3 & 30 & 30 & 25 \\
\hline & 465 & 70 & 45 & 12 & 30 & 5 & 3 & 3 & 40 & 35 & 35 \\
\hline & 570 & 65 & 30 & 11 & 30 & 4 & 4 & 4 & 30 & 30 & 25 \\
\hline Cp. & 870,6 & 91,1 & 56,7 & 17,7 & 60,1 & 6 & 3 & 4,1 & 41,7 & 36,1 & 32,2 \\
\hline
\end{tabular}


Таблица 2. Распределение морфологических признаков Lilium martagon L. (гора Комсомольская)

\begin{tabular}{|c|c|c|c|c|c|c|c|c|c|c|c|}
\hline & 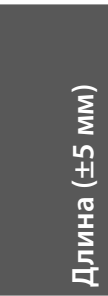 & 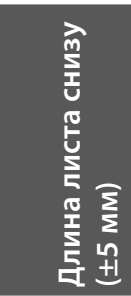 & 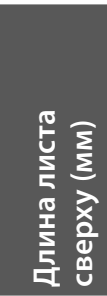 & 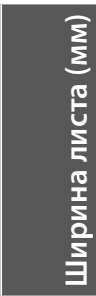 & 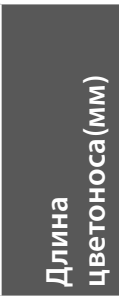 & 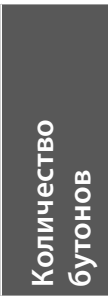 & 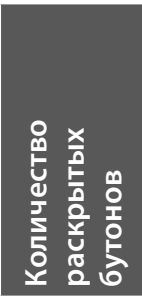 & 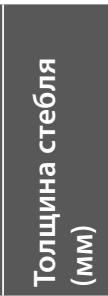 & 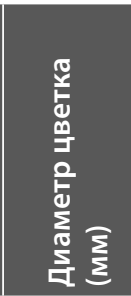 & 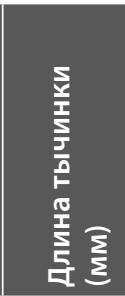 & 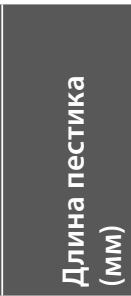 \\
\hline & 1200 & 160 & 50 & 15 & 70 & 6 & 3 & 7 & 35 & 25 & 25 \\
\hline & 755 & 170 & 76 & 14 & 75 & 10 & 5 & 5 & 35 & 30 & 25 \\
\hline & 740 & 97 & 55 & 14 & 63 & 4 & 1 & 5 & 25 & 35 & 30 \\
\hline Cp. & 898,3 & 142,3 & 60,3 & 14,3 & 69,3 & 6 & 3 & 5,7 & 31,7 & 30,0 & 36,7 \\
\hline
\end{tabular}

ном участке, в тени деревьев, были отмечены растения с большей шириной стебля.

Встретилась и такая форма у которой пестик отсутствовал, а так как физических повреждений обнаружено не было то можно судить о том что это генетическая мутация и это растение не сможет размножаться половым путем.

Изучение популяции на горе Комсомольской показало, что Lilium martagon встречается здесь в единичных экземплярах, хотя по опросам местных жителей до 60-х годов 20 века саранка, покрывала весь склон. Снижение численности растений скорее всего способствовало негативное влияние человека, так как на этом месте была обустроена горнолыжная трасса. Вовремя ее прокладки был поврежден верхний поверхностный слой почвы, а в дальнейшем при ее эксплуатации в летнее время осуществляется скашивание высокой травянистой растительности. В результате произошло существенное изменение условий существования растений. Единичные растения которые были отмечены, обнаружены по окраинам трассы на опушке посаженного в прошлом веке соснового бора.

При этом отмечаем, что высота растений, длина листа, длина цветоноса были больше, чем у растений произрастающих на г. Тугая.

Исследование растений произрастающих на приусадебных участках, которые были интродуцированы, дает возможность точно проследить за онтогенезом растений.

Так на первом участке находящемся в с. Чоя Чойского района растения произрастающие в тени плодовых деревьев, первой декаде мая достигли высоты 800 мм, лист снизу равен 50 мм, лист сверху - 30 мм, генеративные органы еще отсутствуют на этом этапе.
Вторая декада характеризуется появлением бутонов их среднее количество равно 8, и увеличением всех размеров в среднем на 15 мм, длина цветоноса равна 30 мм

На момент измерения в третьей декаде мая количество раскрытых бутонов равно 4, диаметр цветка 60 мм, длина тычинок - 25 мм, длина пестика - 20 мм.

Второй участок находиться в с. Ынырга Чойского района,- периодически затеняемый участок, на котором ведется регулярная прополка, по близости практически нет дикорастущих растений, посажены лишь единичные виды декоративных садовых растений.

В первой декаде мая высота составляет 600 мм, длина листа снизу и сверху равны 50 и 30 мм соответственно.

Появление бутонов так же появляется как и в первом случае во второй декаде мая их количество 4 шт., длина цветоноса в этот период составляет 25 мм, высота увеличилась на 270 мм, длинны листьев в среднем на 17 мм.

В третьей декаде высота растения составляет 1100 мм, из 4 бутонов распустилось 3, длина тычинок и пестика - 45 мм, длина листьев увеличилось на 20 мм.

Третий участок находиться та же в селе Ынырга, лилия растет на хорошо освещенном участке вблизи автомобильной дороги.

Здесь в первой декаде мая исследуемое растение уже имеет бутоны в количестве 14 шт., цветонос имеет длину 40мм, длина составляет 700 мм, лист снизу 100 мм, лист сверху 70 мм.

Во второй декаде в основном изменилась только высота она увеличилась почти на треть и уже составляет 900мм, бутоны еще не распустились. 


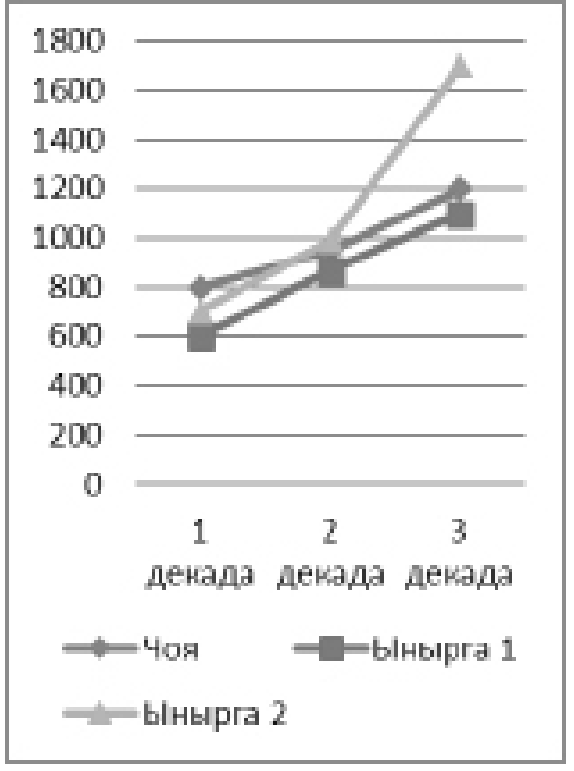

A

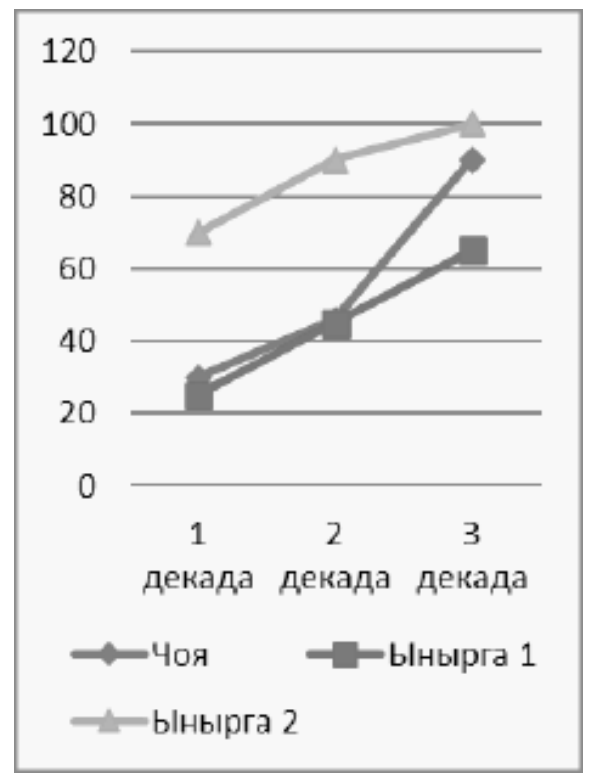

B

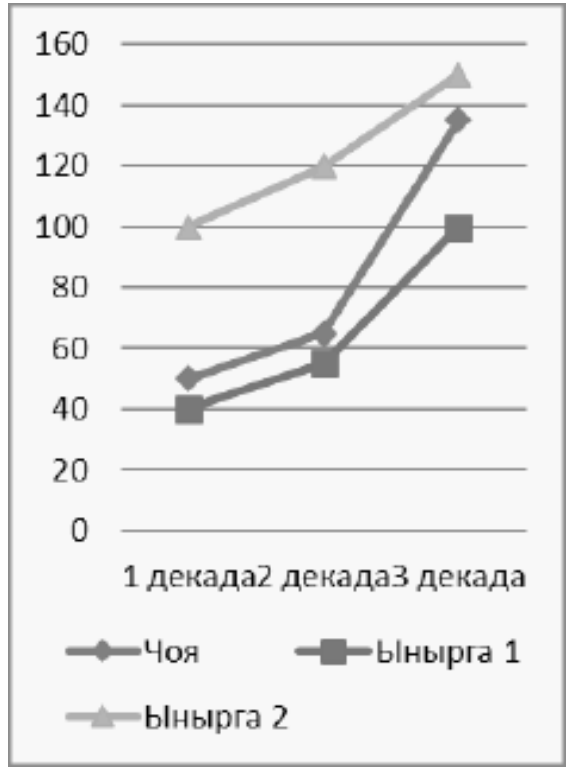

Б

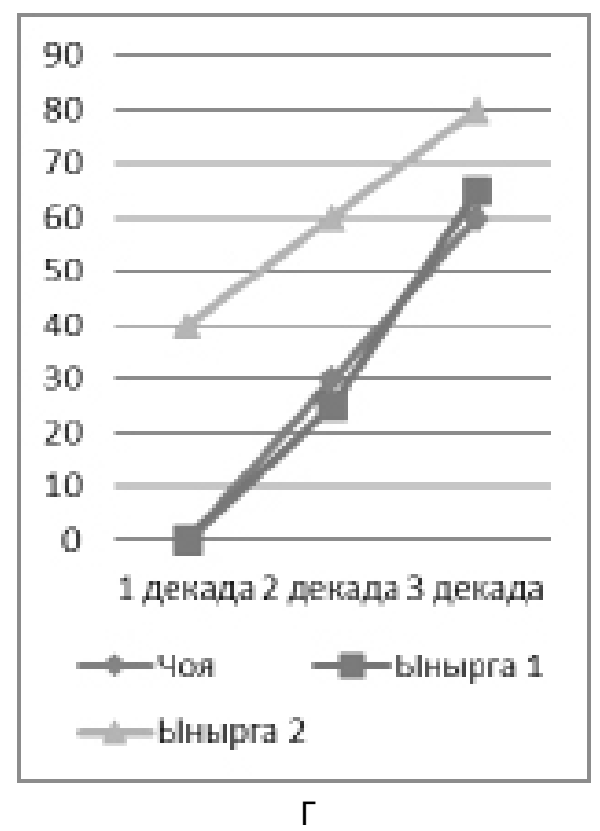

Рис. 1 (продолжение на стр. 17). Сравнительная характеристика разных промеров: А - высота растения, Б - длина листа снизу, В - длина листа сверху, Г - длина цветоноса

В третьей декаде из 14 бутонов 7 начали свое цветение длина пестика и тычинок равны 45мм.

Данные наблюдения позволяют судить о том что период бутонизации, начинается примерно в середине мая, цветение начинается в конце мая. Не зависимо от освещенности изменение высоты примерно происходят в одинаковых темпах, удостовериться в этом можно с помощью представленных ниже диаграмм.
Характер географической изменчивости сорта лилий рассмотрен с помощью многомерного анализа. В качестве статистической основы применен метод главных компонент (Ефимов, Ковалева, 2008; Hotelling, 1933). Анализировалось положение групповых центроидов в пространстве I и II главных компонент. Первая главная компонента снимает 46,01\% исходной дисперсии. Все исходные признаки внесли в первую главную переменную сравнительно одинаковый положительный вклад. Иными словами первую компоненту можно 


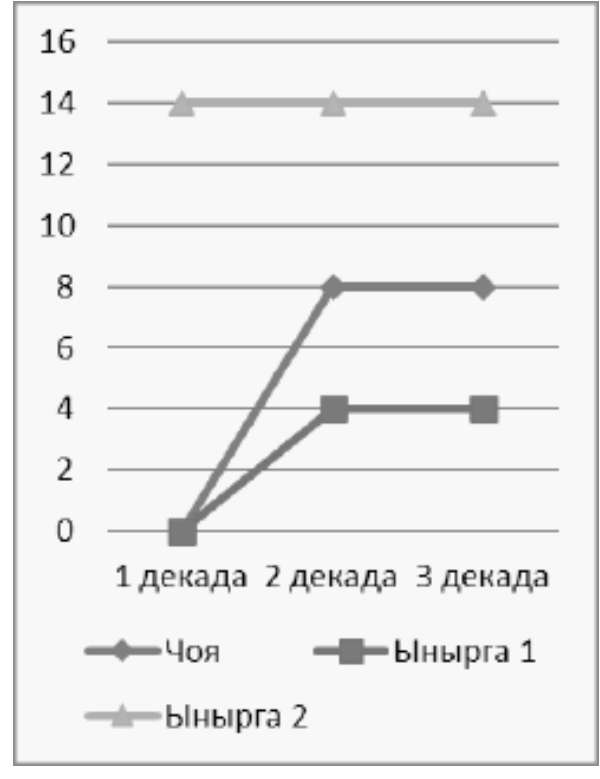

Д

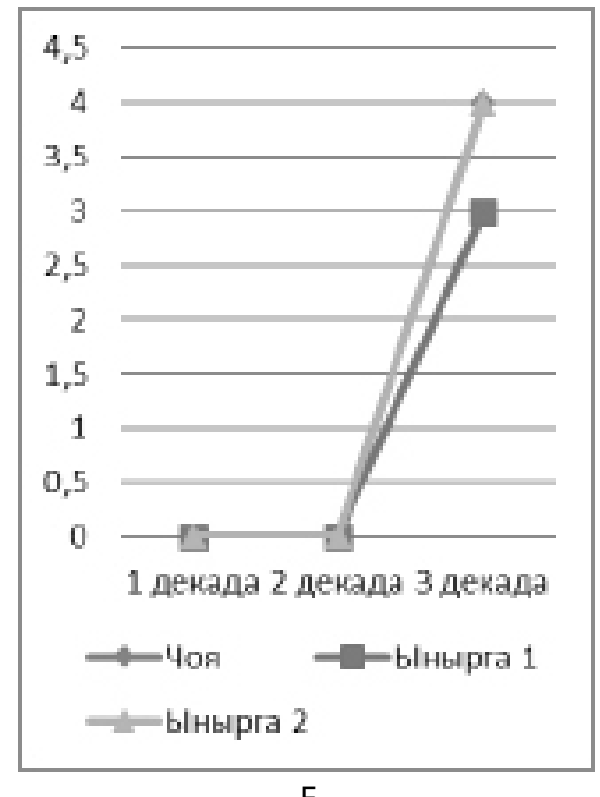

$E$

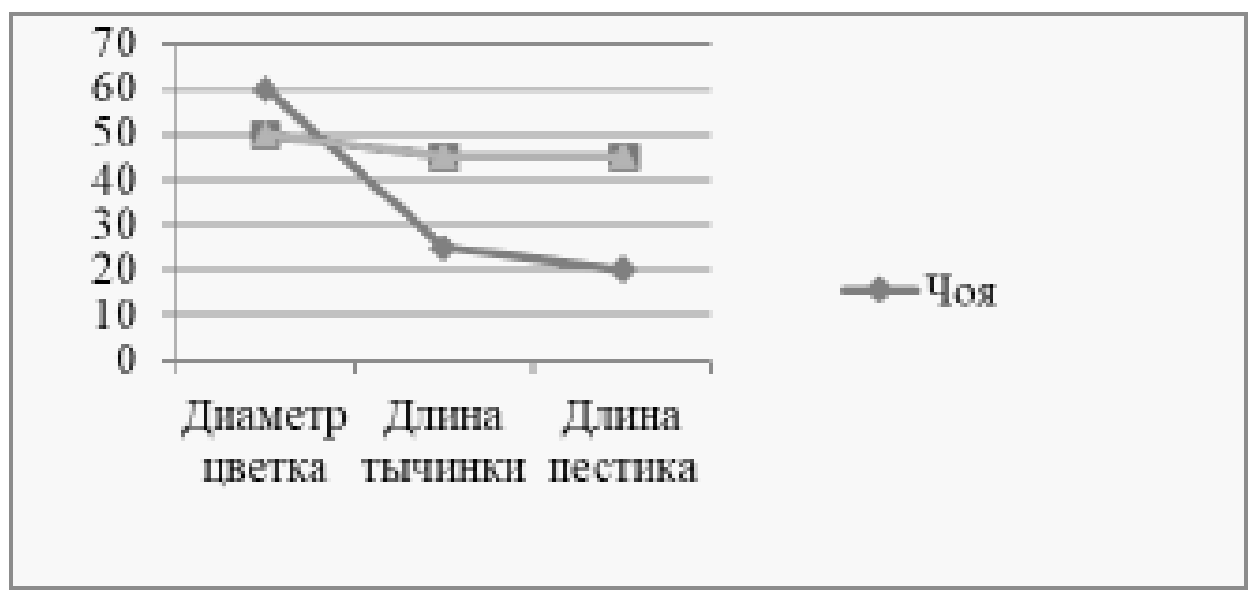

*

Рис. 1 (начало на стр. 16). Сравнительная характеристика разных промеров: Д - количество цветоносов, Е - раскрытых цветов.

считать размерной переменной. Вдоль вектора значений первой компоненты обнаруживаются достоверные отличия между лилиями из двух точек в окрестностях села Ынырга. Чойские и горноалтайсткие растения по этому показателю весьма однородны. В целом направленных различий в абсолютных размерах растений не прослеживается (Рис. 2).

Принципиально иной характер изменчивости серий лилий виден вдоль плоскости второй главной компоненты, отражающей 31,71\% межгрупповой дисперсии. Вдоль ее оси четко разошлись Чойские и Горно-алтайские лилии. Учитывая вклады признаков в главные компоненты можно сказать, что Горно-алтайские лилии имеют более длинные цветоносы и более длинные ли- стья снизу (Таблица 3). Чойские растения отличает более широкий цветок, более длинные тычинки и пестики.

\section{ВывОАы}

Основные морфологические показатели Lilium martagon L. в условиях Северо-Восточного и Северного Алтая не отличаются от показателей других регионов России.

Отмечено, что рост лилии происходит в I-II декаде мая, в зависимости от условий произрастания. Образование первых бутонов наблюдается через 20-30 дней после отрастания. Начало цветения в Lilium martagon 
Таблица 3. Вклады признаков в главные компоненты (х1000)

\begin{tabular}{|l|l|l|}
\hline Признаки & IГК & II ГK \\
\hline Высота растения & 975 & -172 \\
\hline Длина листа снизу & 544 & 777 \\
\hline Длина листа сверху & 971 & 178 \\
\hline Длина цветоноса & 384 & 916 \\
\hline Количество бутонов & 995 & 1 \\
\hline Количество раскрытых бутонов & 755 & -356 \\
\hline Диаметр цветка & 230 & -852 \\
\hline Длина тычинки & 324 & -509 \\
\hline Длина пестика & 309 & -487 \\
\hline
\end{tabular}

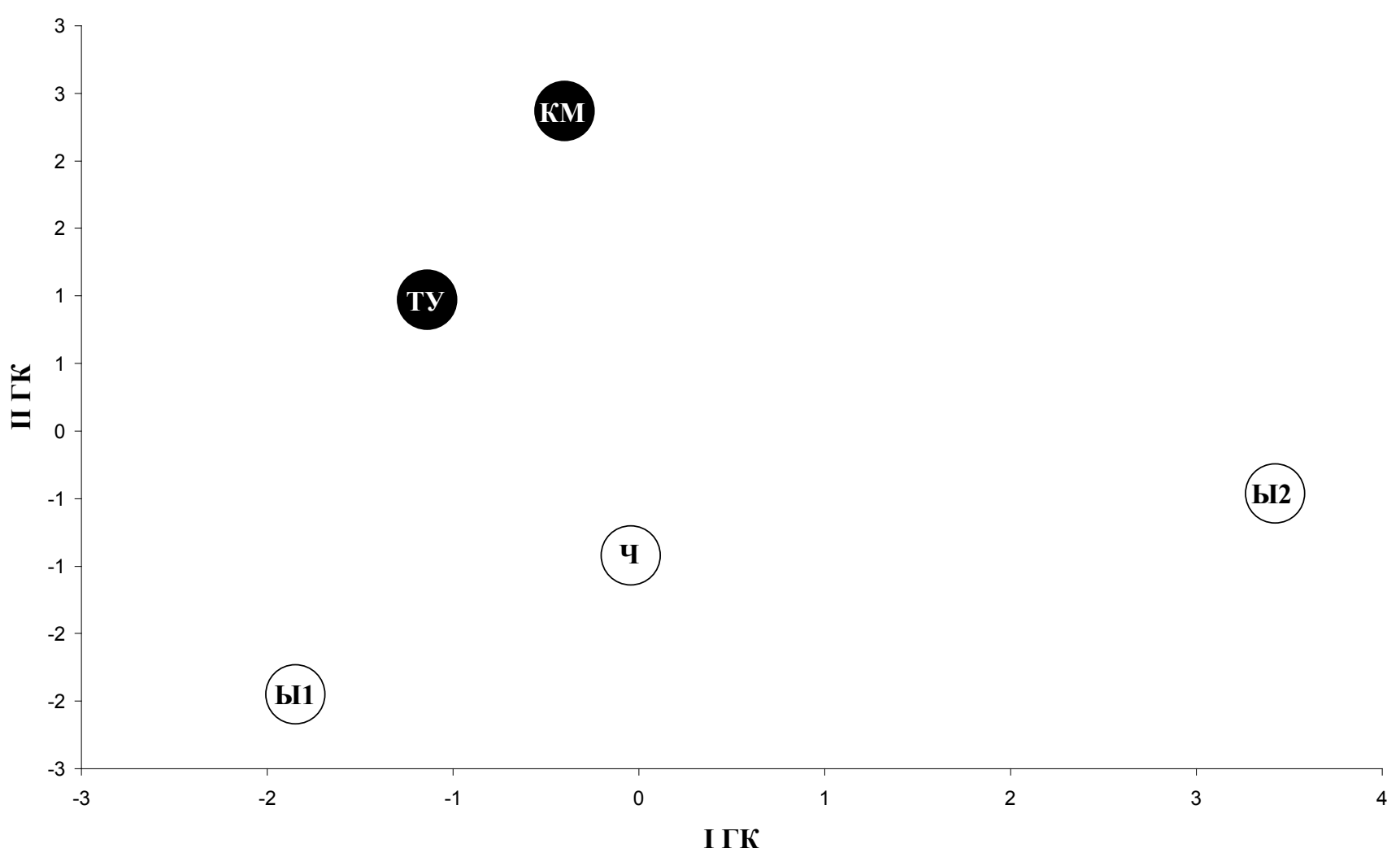

Рис. 2. Распределение центроидов сорта лилий в пространстве первой и второй главных компонент.

Чойские растения показаны белым цветом, Горно-алтайские - черным.

$L$. проводилось через 10-15 дней после бутонизации. Вегетационный период в Алтае длится приблизительно 100 дней.

Природно-климатические условия позволяют данному виду пройти полный цикл сезонного развития.
Благодаря многомерному анализу по методу главных компонент выявлены статистические достоверные различия в изменчивости относительных признаков. Выявленная дистанция между популяциями имеет, скорее всего, адаптивную обусловленность к определенным факторам среды.

\section{ЛИТЕРАТУРА}

1. Баранова М.В. К систематике рода Lilium / М.В. Баранова // Новости систематики высших растений. — 1971. - Т. 8. — С. 89-95с.

2. Доспехов Б.А. Методика полевого опыта [Текст] / Б.А. Доспехов.— М.: Агропромиздат, 1985.—351с. 
3. Злобин Ю.А. Принципы и методы изучения ценотических популяций растений. / Ю.А. Злобин // — Казань, 1989. — 147с.

4. Заливский И.Л. Селекция и интродукция лилий в Ленинграде [Текст] / И.Л. Заливский // Бюл. Гл. ботан. сада. — 1955.—Вып. 23.—C. 14-25.

5. Сафонова 0.В. Культивируемые сорта и гибриды лилий как ресурс биологического разнообразия/ Охрана окружающей среды и природных ресурсов стран Большого Алтая. Материалы Международной научно-практической конференции. Министерство образования и науки Российской Федерации, Русское географическое общество, 2013.- - С. 232-234.

6. Сафонова 0.В., Абрашева А.Е. Изменчивость высоты растений редких для Горного Алтая сортов рода Lilium L. / Проблемы ботаники Южной Сибири и Монголии. № 13, 2014. - С. 183-186.

7. Сафонова 0.В., Софина М.П. Изменчивость морфологических признаков Lilium marnagon L. в условиях Северного Алтая / Материалы Первого Алтаистического Форума «Тюрко-Монгольский Мир Большого Алтая: Историко-Культурное Наследие И Современность», Ответственный редактор Р.И. Райкин, 2019.-С. 376-378.

8. Сорокопудова 0.А. Биологические особенности лилий в Сибири [Текст] / 0.А. Сорокопудова. — Белгород: Изд-во БелГУ, 2005.- 244c.

9. Федорова Н.К. Лилии [Текст] / Н.К. Федорова.—М.: Кладезь Букс, 2005.—95с.

10. Elwes H.S. Monograph of the genius Lilium. / H.S. Elwes. — London, 1880

() Петунина Светлана Сергеевна ( petunina-sveta@mail.ru ),Сафонова Оксана Владимировна ( oksvarias@mail.ru ),

Худякова Надежда Ефремовна ( Nch752@bk.ru), Конокпоева Любовь Александровна ( konokpoeva92@gmail.com ),

Шмакова Наталья Юрьевна ( Nataliashmakova1998@gmail.com ).

Журнал «Современная наука: актуальные проблемы теории и практики»

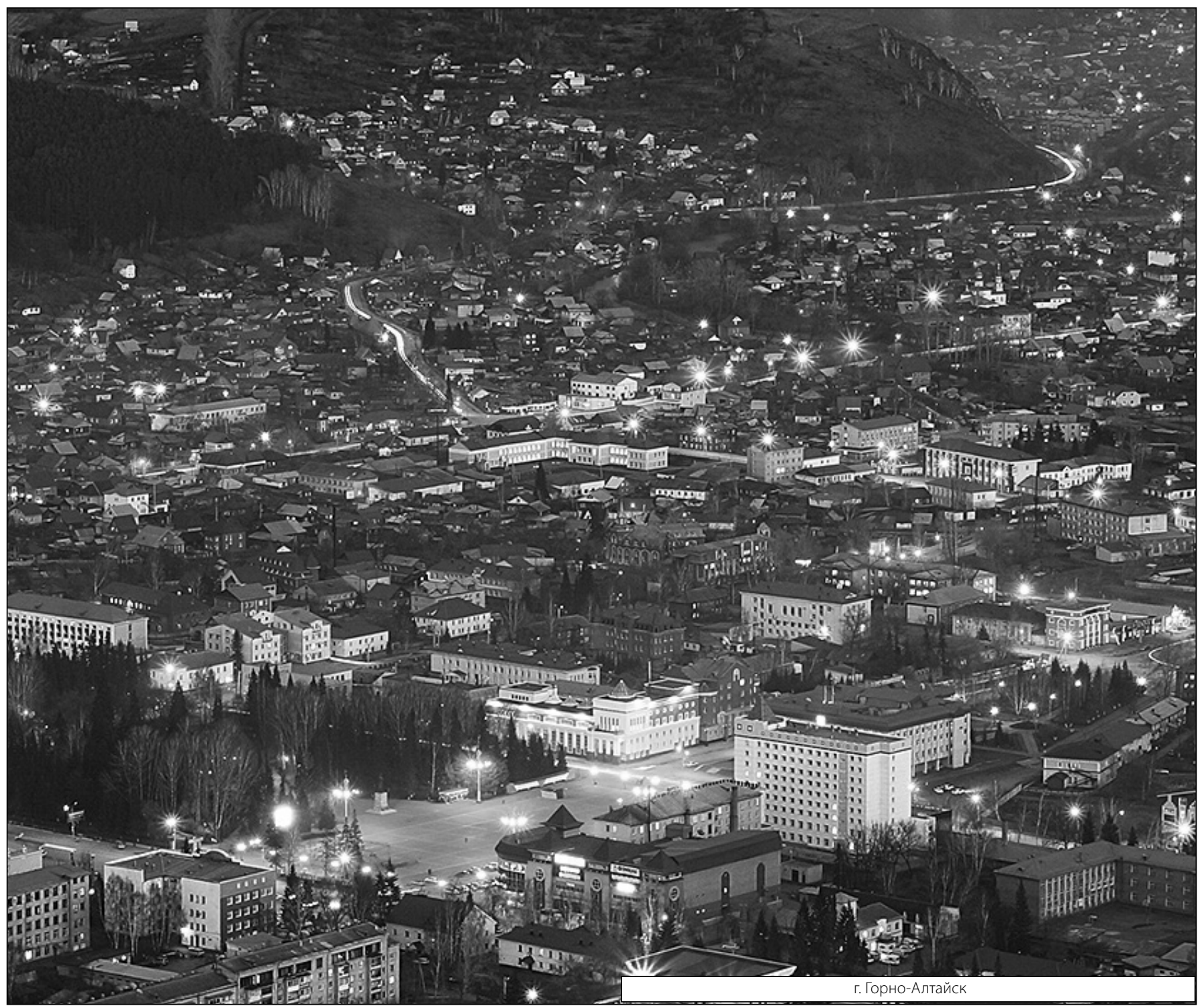

